University of Pittsburgh School of Law

Scholarship@PITT LAW

Articles

Faculty Publications

$12-2015$

\title{
Comments on Proposed Treasury Regulations Defining Terms Relating to Marital Status
}

Anthony C. Infanti

University of Pittsburgh School of Law, infanti@pitt.edu

The American Bar Association

Follow this and additional works at: https://scholarship.law.pitt.edu/fac_articles

Part of the Civil Rights and Discrimination Commons, Dispute Resolution and Arbitration Commons, Estates and Trusts Commons, Family Law Commons, Law and Economics Commons, Law and Gender Commons, Law and Society Commons, Legislation Commons, Public Law and Legal Theory Commons, Sexuality and the Law Commons, Tax Law Commons, and the Workers' Compensation Law Commons

\section{Recommended Citation}

Anthony C. Infanti \& The American Bar Association, Comments on Proposed Treasury Regulations Defining Terms Relating to Marital Status, (2015).

Available at: https://scholarship.law.pitt.edu/fac_articles/343

This Article is brought to you for free and open access by the Faculty Publications at Scholarship@PITT LAW. It has been accepted for inclusion in Articles by an authorized administrator of Scholarship@PITT LAW. For more information, please contact leers@pitt.edu, shephard@pitt.edu. 
OFFICERS Chair
George C. Howell, II
Richmond, VA
Chair-Elec

William H. Caudill

Houston, TX

Vice Chairs

Administration

Charles P. Rettig

Beverly Hills, CA

Committee Operations

Thomas J. Callahan Cleveland, $\mathrm{OH}$

Continuing Legal Education

Joan C. Arnold

Philadelphia, PA

Government Relations

Peter H. Blessing

Pro Bono and Outreach

C. Wells Hall, III

Charlotte, NC

Publications

Julie A. Divola

San Francisco, CA

Secretary

Catherine B. Engel

New York, NY

Assistant Secretary

Katherine E. David

San Antonio, TX

COUNCIL

Section Delegates to the

House of Delegates

Richard M. Lipton Chicago, IL

Susan P. Serota

New York, NY

Last Retiring Chair

Armando Gomez

Washington, DC Members

Megan L. Brackne

New York, NY

Lucy W. Far

New York, NY

Mary A. McNulty Dallas, TX

John O. Tannenbaum

Stewart M. Weintraub

West Conshohocken, PA Alan I. Appel

Larry A. Campagna Houston, TX

T. Keith Fogg Villanova, PA

Kurt L.P. Lawson

Washington, DC

Cary D. Pugh

Washington, DC

John F. Bergner

Dallas, TX

Thomas D. Greenaway Boston, MA

Roberta F. Mann

Eugene, OR

Carol P. Tello

Washington, DC

Gary B. Wilcox

Washington, DC

LIAISONS

Board of Governors

Pamela A. Bresnahan Washington, DC

Young Lawyers Division

Travis A. Greaves

Washington, DC

Law Student Division

Melissa M. Gilchrist

Hamtramck, Ml

DIRECTOR

Janet J. In

Washington, DC
The Honorable John Koskinen

Commissioner

Internal Revenue Service

1111 Constitution Avenue, NW

Washington, DC 20224

Re: Comments on Definition of Terms Relating to Marital Status

Dear Commissioner Koskinen:

Enclosed please find comments on proposed regulations regarding definition of terms relating to marital status ("Comments"). These Comments are submitted on behalf of the American Bar Association Section of Taxation and have not been approved by the House of Delegates or the Board of Governors of the American Bar Association. Accordingly, they should not be construed as representing the position of the American Bar Association.

The Section of Taxation would be pleased to discuss the Comments with you or your staff if that would be helpful.

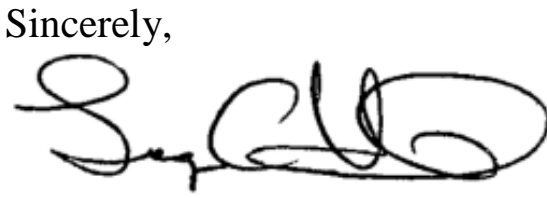

George C. Howell, III

Chair, Section of Taxation

Enclosure

CCs: William Wilkins, Chief Counsel, Internal Revenue Service

Erik Corwin, Deputy Chief Counsel (Technical), Internal Revenue Service

Drita Tonuzi, Associate Chief Counsel (Procedure \& Administration), Internal Revenue Service

Nina Olson, National Taxpayer Advocate

Mark Mazur, Assistant Secretary (Tax Policy), Department of the Treasury

Emily McMahon, Deputy Assistant Secretary (Tax Policy), Department of the Treasury 


\section{AMERICAN BAR ASSOCIATION SECTION OF TAXATION}

\section{COMMENTS ON PROPOSED REGULATIONS REGARDING DEFINITION OF TERMS RELATING TO MARITAL STATUS}

These comments ("Comments") are submitted on behalf of the American Bar Association Section of Taxation (the "Section") and have not been approved by the House of Delegates or Board of Governors of the American Bar Association. Accordingly, they should not be construed as representing the position of the American Bar Association.

Principal responsibility for preparing these Comments was exercised by Anthony C. Infanti, Chair of the Section's Teaching Taxation Committee (the "Committee"). Substantive contributions were made by Patricia A. Cain, Bridget Crawford, David Herzig, and Theodore Seto of the Committee; and by George Karibjanian of the Section's Estate \& Gift Tax Committee. The Comments were further reviewed by Danshera Cords of the Section's Committee on Government Submissions; by Keith Fogg, the Section's Council Director for the Committee; and by Peter Blessing, the Section's Vice Chair (Government Relations).

Although the members of the Section of Taxation who participated in preparing these Comments have clients who might be affected by the federal tax principles addressed by these Comments, no such member or the firm or organization to which such member belongs has been engaged by a client to make a government submission with respect to, or otherwise to influence the development or outcome of, the specific subject matter of these Comments. Additionally, while the Section's diverse membership includes government officials, no such official was involved in any part of the drafting or review of these Comments.

Contact: $\quad$ Anthony C. Infanti

Tel.: (412) 648-1244

Email: infanti@pitt.edu

Date: $\quad$ December 3, 2015 


\section{EXECUTIVE SUMMARY}

These Comments respond to the recently proposed regulations defining terms relating to marital status in the Internal Revenue Code. The Comments applaud the Internal Revenue Service (the "Service") for reading gendered terms relating to marital status in a gender-neutral fashion. For a number of reasons, however, these Comments recommend that the final Regulations omit the proposed rule for determining an individual's marital status and, in its place, codify the current deference to local law in determining marital status. These Comments further recommend that the final Regulations reverse the current position of the Service regarding domestic partnerships, civil unions, and similar relationships and instead recognize those relationships for federal tax purposes. 


\section{DISCUSSION}

The following Comments respond to the invitation from the Service for comments regarding a notice of proposed rulemaking published in the Federal Register on October 23, 2015. ${ }^{1}$ This notice of proposed rulemaking contains proposed amendments to the Regulations under section $7701^{2}$ (the "Proposed Regulations") that are intended to define terms in the Code relating to marital status in ways that reflect the holdings of the U.S. Supreme Court in Obergefell v. Hodges ${ }^{3}$ and United States v. Windsor. ${ }^{4}$ The Proposed Regulations, though brief, provide guidance to taxpayers regarding three important questions raised by the Obergefell and Windsor decisions. The Proposed Regulations (1) read the gendered references to "husband" and "wife" in the Code as including married same-sex couples, ${ }^{5}(2)$ set forth a specific rule for determining when two individuals will be considered "married" for federal tax purposes, ${ }^{6}$ and (3) deny legal recognition for federal tax purposes to individuals who have entered into a domestic partnership, civil union, or similar legal relationship that is not specifically denominated a "marriage."" These Comments will address each of these pieces of guidance separately below.

\section{Gendered References to Marital Status}

In keeping with the spirit of the U.S. Supreme Court's decisions in the Windsor and Obergefell cases (as well as earlier guidance issued by the Service on this question ${ }^{8}$ ), the Proposed Regulations read the terms "husband" and "wife" in a gender-neutral fashion for federal tax purposes. We commend the Service for adopting this approach to interpreting the Code, as it ensures equal treatment of married couples regardless of their composition or sexual orientation.

\section{Determining Marital Status}

The Proposed Regulations provide that "[a] marriage of two individuals is recognized for federal tax purposes if the marriage would be recognized by any state, possession, or territory of the United States." ${ }^{9}$ Based on the explanation in the preamble to the Proposed Regulations, this formulation of the rule for determining marital status seems to have been driven by concerns regarding the recognition of marriages celebrated outside of the United States. ${ }^{10}$ While laudable in its ostensible attempt to ensure the recognition of same-sex marriages celebrated outside of the United States in the pre-Obergefell era, this rule is problematic because it may produce unintended adverse consequences and may generate both uncertainty in the administration of the federal tax laws and unnecessary litigation regarding questions of taxpayers' marital status.

\footnotetext{
${ }^{1}$ Definition of Terms Relating to Marital Status, 80 Fed. Reg. 64,378 (proposed Oct. 23, 2015) (to be codified at 26 C.F.R. pts. 1, 20, 25, 26, 31, \& 301).

${ }^{2}$ References to a "section" are to a section of the Internal Revenue Code of 1986, as amended (the "Code"), unless otherwise indicated.

${ }^{3} 576$ U.S. _ 135 S. Ct. 2584 (2015).

${ }^{4} 570$ U.S. $— 133$ S. Ct. 2675 (2013).

${ }^{5}$ Prop. Reg. § 301.7701-18(a), 80 Fed. Reg. 64,378, 64,380 (2015).

${ }^{6}$ Prop. Reg. $\$ 301.7701-18(b), 80$ Fed. Reg. 64,378, 64,380 (2015).

${ }^{7}$ Prop. Reg. § 301.7701-18(c), 80 Fed. Reg. 64,378, 64,380-81 (2015).

${ }^{8}$ Rev. Rul. 2013-17, 2013-38 I.R.B. 201.

${ }^{9}$ Prop. Reg. § 301.7701-18(b), 80 Fed. Reg. 64,378, 64,380 (2015).

${ }^{10}$ Definition of Terms Relating to Marital Status, 80 Fed. Reg. 64,378, 64,379 (proposed Oct. 23, 2015) (to be codified at 26 C.F.R. pts. $1,20,25,26,31, \& 301$ ).
} 
First, the Proposed Regulations appear to be inconsistent with longstanding conflict of laws rules regarding the determination of the validity of a marriage. Naturally, as rules that are intended to resolve the application of the conflicting laws of multiple states, these rules do not simply validate marriages that any state, possession, or territory would recognize — as the Proposed Regulations would do. Rather, these conflict of laws rules aim to guide the determination of which state's laws should govern the determination of the validity of a marriage. Thus, section 283(2) of the Restatement (Second) of Conflict of Laws provides that "[a] marriage which satisfies the requirements of the state where the marriage was contracted will everywhere be recognized as valid unless it violates the strong public policy of another state which had the most significant relationship to the spouses and the marriage at the time of the marriage." Relying on this rule, the Missouri courts have, for example, invalidated common law marriages purportedly entered into by Missouri domiciliaries while temporarily visiting other states where common law marriage is recognized, because to do otherwise would violate Missouri's strong public policy against common law marriage. ${ }^{11}$ Yet, because the Proposed Regulations would recognize a marriage for federal tax purposes so long as "any state" would recognize that marriage, it could be argued that the Proposed Regulations actually mandate recognition of these invalid common law marriages for federal tax purposes. The rule in the Proposed Regulations thus seriously risks undermining established state law and public policy by displacing the traditional deference to state law on questions regarding marital status with what is, in essence, a federal law of marriage. Concomitantly, the rule in the Proposed Regulations risks sowing uncertainty regarding a couple's marital status that may generate unnecessary litigation to resolve marital status questions that have already been resolved in state court.

Second, the Proposed Regulations appear to inadvertently wade into the conflicting case law regarding the determination of marital status following divorce. The Service's longstanding position on this question was published in Revenue Ruling 67-442. That ruling announced that the Service:

generally will not question for Federal income tax purposes the validity of any divorce decree until a court of competent jurisdiction declares the divorce to be invalid. However, where a state court, in a proceeding in which there is personal jurisdiction of the parties or jurisdiction of the subject matter of the action, declares the prior divorce to be invalid, the Service will usually follow the later court decision rather than the divorce decree for Federal income tax purposes for such years as may not be barred by the statute of limitations. ${ }^{12}$

Though not patently inconsistent with this position, the Proposed Regulations could easily come into conflict with the position announced in Revenue Ruling 67-442. For example, in keeping with its announced position, the Service has in the past refused to treat a couple as married even where there are doubts about the validity of a divorce, so long as no court of competent jurisdiction has called the validity of the divorce into question. ${ }^{13}$ The Proposed Regulations, however, would treat a couple as married so long as any state, possession, or territory would

\footnotetext{
${ }^{11}$ Stein v. Stein, 641 S.W.2d 856 (Mo. Ct. App. 1982); Hesington v. Estate of Hesington, 640 S.W.2d 824 (Mo. Ct. App. 1982); see also Olsen v. Bowen, No. 87-0646-CV-W-6, 1989 WL 29918 (W.D. Mo. Jan. 12, 1989) (applying Stein and Hesington).

${ }^{12}$ Rev. Rul. 67-442, 1967-2 C.B. 65.

${ }^{13}$ E.g., Estate of Felt v. Commissioner, 54 T.C.M. (CCH) 528, 1987 T.C.M. (RIA) II 87,465.
} 
recognize their marriage. In view of the phrasing of the Proposed Regulations, which only require that the marriage "would be recognized" by any state, territory, or possession, it appears that the Proposed Regulations would require the Service to treat a couple as married whenever there are doubts about the validity of a divorce and the Service determines that those doubts are well-founded - even if no court of competition jurisdiction has called the validity of the divorce into question. Thus, if finalized, the Proposed Regulations would open the door to recognizing marriages in situations that conflict with the Service's longstanding position on this question.

Third, a question left open by the Proposed Regulations is how the rule for determining marital status would apply to those whose marital status is relevant for federal tax purposes, but who were married outside the United States (other than in a territory or possession) and are domiciled in a foreign country. This would include, for example, U.S. citizens who are taxed on their worldwide income, but who were living abroad both before and after they were married in a foreign country. Would these taxpayers be required to study the laws of every U.S. state, possession, and territory to determine whether their marriage would be recognized? And, if so, under what circumstances would they make this determination (e.g., would they assume relocation to the state, travel through the state, a short visit to the state, etc.), should such facts be relevant in weighing whether the jurisdiction would recognize the marriage as a matter of comity (e.g., if there are potentially conflicting local public policy concerns that might lead the jurisdiction to deny recognition to the marriage)?

Finally, the rule in the Proposed Regulations regarding the determination of marital status is, in operation, fundamentally incompatible with the separate provision in the Proposed Regulations that denies legal recognition to domestic partnerships, civil unions, and similar legal relationships that are not denominated a "marriage" by the relevant jurisdiction. As described more fully in the next section of these Comments, several states recognize these alternative relationships as valid marriages, which would seem to require their recognition for federal tax purposes under the rule in the Proposed Regulations for determining marital status.

In light of the numerous problems raised by the rule in the Proposed Regulations regarding determinations of marital status, we recommend that the Regulations, when finalized, simply state that determinations of an individual's marital status will be made under the laws of the relevant state, possession, or territory of the United States or, where appropriate, under the laws of the relevant foreign country (e.g., the country where the marriage was celebrated or another country, if conflict of laws questions arise). This alternative position would codify existing law without raising the many thorny issues discussed above.

\section{Alternatives to Marriage}

The Proposed Regulations deny recognition for federal tax purposes to any relationship that is not denominated a marriage under the law of a state, possession, or territory - even if that relationship entails the same rights and obligations as a marriage under that jurisdiction's laws. ${ }^{14}$ The preamble to the Proposed Regulations justifies this position, which was originally articulated without explanation in Revenue Ruling 2013-17 ${ }^{15}$ shortly after the Windsor decision, on the grounds that: (1) the Service has traditionally deferred to the states in defining what constitutes a

\footnotetext{
${ }^{14}$ Prop. Reg. § 301.7701-18(c), 80 Fed. Reg. 64,378, 64,380-81 (2015).

${ }^{15}$ 2013-38 I.R.B. 201.
} 
"marriage," (2) recognizing these alternative legal relationships would frustrate the expectations of those who have entered into them, and (3) there is no specific Code provision that requires the treatment of these relationships as a marriage for federal tax purposes. This position is seriously flawed and, for the reasons described below, we recommend that the final Regulations reverse this position.

\section{Deferring to the States}

By denying recognition to domestic partnerships, civil unions, and other legal relationships that are intended to be the equivalent of marriage, the Service does not actually defer to the states but rather disregards the intent of the states in creating these alternative legal relationships. The small minority of states ${ }^{16}$ that have adopted these alternative legal relationships did so prior to the Windsor and Obergefell decisions in an effort to grant same-sex couples all of the rights and obligations of marriage but without attaching the marriage label to their relationships because it was politically infeasible to do so at the time and, in some states, categorically prohibited by their state constitutions. ${ }^{17}$ The Service indicates in the preamble to the Proposed Regulations that these states "carefully considered the types of relationships that they choose to recognize as a marriage and the types that they choose to recognize as something other than a marriage." 18 However, this careful consideration did not revolve around the nature of the relationships themselves - as they often entail precisely the same set of rights and obligations - but instead who would be entering into those relationships. The state legislatures were in most cases limited in their ability to recognize same-sex relationships either as a political matter or by a state constitutional provision that banned them from enacting legislation extending "marriage" to same-sex couples. It is also important to bear in mind that when they first appeared on the scene, civil unions and domestic partnerships were heralded as granting full equality to same-sex couples, but within a short time came to be seen as doing nothing more than relegating same-sex couples to a second-class, separate-but-equal status. ${ }^{19}$ With this history in mind, it becomes clear that to deny legal recognition to these relationships based on the label applied to them-especially, but not exclusively, in open years when these relationships were the only legal status available to same-sex couples - would make the Service a party to the very sort of

\footnotetext{
${ }^{16}$ Nine states and the District of Columbia have created marriage alternatives. Marriage Equality and Other Relationship Recognition Laws, HuM. RTS. CAMPAIGN (Aug. 11, 2015), http://www.hrc.org/state_maps.

${ }^{17}$ E.g., COLO. REV. STAT. ANN. § 14-15-102 (2015) (in the legislative declaration preceding the state's civil union law, stating "The general assembly declares that the public policy of this state, as set forth in section 31 of article II of the state constitution, recognizes only the union of one man and one woman as a marriage. ... The general assembly finds that the 'Colorado Civil Union Act' does not alter the public policy of this state, which recognizes only the union of one man and one woman as a marriage.”); NEV. REV. STAT. ANN. § 122A.510 (2015) (stating that "[a] domestic partnership is not a marriage for the purposes of Section 21 of Article 1 of the Nevada Constitution," which provides that "[o]nly a marriage between a male and female person shall be recognized and given effect in this state," NEV. Const. art. 1, § 21, declared unconstitutional by Latta v. Otter, 711 F.3d 456 (2014)); OR. REV. STAT. ANN. § 106.305(7) (2015) ("The Legislative Assembly recognizes that the Oregon Constitution limits marriage to the union of one man and one woman. The Legislative Assembly does not seek to alter this definition of marriage in any way through the Oregon Family Fairness Act and recognizes that the Legislative Assembly cannot bestow the status of marriage on partners in a domestic partnership.").

${ }^{18}$ Definition of Terms Relating to Marital Status, 80 Fed. Reg. 64,378, 64,379 (proposed Oct. 23, 2015) (to be codified at 26 C.F.R. pts. 1, 20, 25, 26, 31, \& 301).

${ }^{19}$ Douglas NeJaime, Framing (In)Equality for Same-Sex Couples, 60 UCLA L. REV. DisCOURSE 184 (2013), http://www.uclalawreview.org/framing-inequality-for-same-sex-couples/.
} 
discrimination that the U.S. Supreme Court declared unconstitutional in Obergefell and Windsor and that the Service is attempting to remedy through the Proposed Regulations.

To truly defer to the states, the Service should ignore the labels applied to these alternative relationships and be guided instead by their legal equivalence to marriage under state law in determining their federal tax treatment. For example, the California statute prescribing the rights and obligations of registered domestic partners provides that those rights and obligations are the same as those of married spouses:

Registered domestic partners shall have the same rights, protections, and benefits, and shall be subject to the same responsibilities, obligations, and duties under law, whether they derive from statutes, administrative regulations, court rules, government policies, common law, or any other provisions or sources of law, as are granted to and imposed upon spouses. ${ }^{20}$

And like the Service in the Proposed Regulations, to effect this intent, California has mandated a gender-neutral interpretation of gendered terms relating to marital status when applied to samesex domestic partners: "Where necessary to implement the rights of registered domestic partners under this act, gender-specific terms referring to spouses shall be construed to include domestic partners. ${ }^{, 21}$ Further evidencing its intent to treat domestic partners as married for purposes of state law, California even goes so far as to override federal law denying legal recognition to domestic partners where it would frustrate the intent of the state in adopting its domestic partnership regime:

To the extent that provisions of California law adopt, refer to, or rely upon, provisions of federal law in a way that otherwise would cause registered domestic partners to be treated differently than spouses, registered domestic partners shall be treated by California law as if federal law recognized a domestic partnership in the same manner as California law. ${ }^{22}$

Similarly, New Jersey affords couples who have entered into a civil union the same rights and obligations as married spouses. ${ }^{23}$ Notably, in doing so, New Jersey has located its statutory provisions regarding civil unions in the same title with the statutory provisions governing marriages; that is, in "Title 37, Marriages and Married Persons." Moreover, though including several provisions specific to civil unions in this title, the New Jersey legislature chose to amend many of the general provisions regarding the requisites for entering into a legal marriage to simultaneously refer to marriages and civil unions rather than repeating those provisions with respect to each legal status in separate statutory provisions. ${ }^{24}$

Illinois likewise affords parties to a civil union the same rights and obligations as married spouses. ${ }^{25}$ When Illinois extended marriage to same-sex couples through its Religious Freedom

${ }^{20}$ CAL. FAM. CODE $§ 297.5$ (a) (2015).

${ }^{21}$ CAL. FAM. CODE $§ 297.5(\mathrm{j})(2015)$.

${ }^{22}$ CAL. FAM. CODE $§ 297.5(\mathrm{e})(2015)$.

${ }^{23}$ N.J. STAT. ANN. § 37:1-31, -33 (2015).

${ }^{24}$ E.g., N.J. STAT. ANN. § 37:1-1 to -8 (2015).

${ }^{25} 750$ ILL. COMP. STAT. ANN. § 75/20 (2015). 
and Marriage Fairness Act ("Act"), ${ }^{26}$ it enacted a statutory provision permitting parties to a civil union to convert their civil union into a marriage during the one-year period following enactment of the Act. ${ }^{27}$ Evidencing the state's obvious recognition of the equivalence of these legal statuses, the date of marriage for a couple converting their civil union to a marriage under this provision relates back to the earlier date of solemnization of the civil union. ${ }^{28}$

Similar treatment of converted civil unions can be found in Delaware. Delaware ended its civil union regime when it extended the right to marry to same-sex couples. ${ }^{29}$ Following a oneyear period during which couples could convert their civil unions into marriages, Delaware converted all remaining civil unions into marriages by operation of law, with the date of marriage relating back to the earlier date of solemnization of the civil union. ${ }^{30}$

These examples make it clear that refusing legal recognition to civil unions and domestic partnerships that are intended by a state to be - and are treated by a state as - the legal equivalent of a marriage in no way defers to that state's judgment in defining marital status. To truly defer to the state's judgment, labels that were applied as a matter of political expediency or constitutional mandate and that quickly came to be seen as a mark of unconstitutional discrimination should not control the tax treatment of couples who share the same rights and obligations to each other as do married spouses. Looking past these labels to the actual rights and obligations of the parties to the relationship would not only better effectuate the Service's professed intention to defer to a state's judgment in defining marital status, but would also be fully in keeping with the doctrine of substance over form, which has been described as "the cornerstone of sound taxation.",31

\section{Frustrated Expectations}

The preamble to the Proposed Regulations also justifies the denial of legal recognition to domestic partnerships, civil unions, and similar legal relationships on the ground that to do otherwise would frustrate the expectations of those who have entered into these relationships. The preamble posits that some couples might have entered into these relationships "with the expectation that their relationship will not be treated as a marriage for purposes of federal law." 32 For instance, the preamble suggests that these couples might have expected to avoid the marriage penalty or to reap Social Security benefits that they would not be entitled to receive were they to marry. ${ }^{33}$

First, it is difficult to understand how these couples could have expected anything other than that their relationships would be treated as marriages for federal tax purposes. Two years prior to the Windsor decision, the Service indicated in response to an inquiry from H\&R Block that a different-sex couple in a civil union could file a joint federal income tax return if their

2013 ILL. LEGis. SERV. P.A. 98-597 (S.B. 10) (West).

${ }^{27} 750$ ILL. COMP. STAT. ANN. § 75/65(b) (2015).

${ }^{28} 750$ Ill. COMP. STAT. ANN. § 75/65(b) (2015).

${ }^{29}$ Del. CODE ANN. tit. 13, § 218(a) (2015).

${ }^{30}$ DeL. CodE ANN. tit. 13, § 218(c) (2015). The only civil unions exempted from this provision were those that were already in the process of dissolution. DEL. CODE ANN. tit. 13, § 218(d) (2015).

${ }^{31}$ Estate of H.H. Weinert v. Commissioner, 294 F.2d 750, 755 (5th Cir. 1961).

${ }^{32}$ Definition of Terms Relating to Marital Status, 80 Fed. Reg. 64,378, 64,379 (proposed Oct. 23, 2015) (to be codified at 26 C.F.R. pts. $1,20,25,26,31, \& 301)$.

${ }^{33} I d$. 
relationship was legally equivalent to a marriage under state law. ${ }^{34}$ This guidance from the Service received significant attention within the tax community. ${ }^{35}$ Given this informal guidance from the Service, it is more likely that couples who had entered into civil unions and domestic partnerships were frustrated when the Service decided to reverse course and deny their relationships legal recognition following the Windsor decision. ${ }^{36}$

Second, the Service's discussion of frustrated expectations is premised on notions of voluntariness in entering into a relationship status or in deciding not to convert from an alternative legal relationship to marriage (once marriage became available to same-sex couples). There may certainly be some taxpayers who were (or are) in this situation of making a choice not to marry. However, when these statuses were created, same-sex couples had no choice at all between statuses. A civil union, domestic partnership, or other alternative legal relationship was their only option.

Among the same-sex couples who entered into an alternative legal relationship when that was the only choice available to them, there are some who have remained in that alternative legal relationship not because of a voluntary choice but because one member of the couple has died, become incapacitated, or otherwise lacks the capacity to enter into a marriage. These couples are trapped in this alternative legal relationship and, since the issuance of Revenue Ruling 2013-17, the Service has denied them access to the legal certainty associated with having their relationship treated as a marriage for federal tax purposes and has added to the complexity of their state income tax filings (because their relationships may be recognized for state tax purposes but not for purposes of their federal income tax returns, which often serve as a starting point for calculating their state income taxes). ${ }^{37}$

Others may have resisted entering into or converting their relationship into a marriage because of principled opposition to the institution of marriage.. When these couples dissolve their relationships they are required to go through the same processes that spouses go through in a divorce. Alimony obligations are calculated in the same way, and property divisions occur in the same way as for spouses. Yet, under the position articulated in Rev. Rul. 2013-17 and the Proposed Regulations, the Service declines to allow these couples the certainty of tax treatment associated with sections 71, 215, and 1041—not to mention the possibility of splitting retirement benefits under $\S 414(\mathrm{p})$ or the benefit of the gift and estate tax marital deductions in sections 2523 and 2056. These couples are left to navigate the tax treatment of their breakup with little or no guidance from the Service whatsoever.

\footnotetext{
${ }^{34}$ Letter from Pamela Wilson Fuller, Senior Technician Reviewer, Internal Revenue Serv., to Robert Shair, Senior Tax Advisor, H\&R Block (Aug. 30, 2011) (LEXIS, FEDTAX lib., TNT file, elec. cit. 2011 TNT 215-62).

${ }^{35}$ E.g., Amy S. Elliott, IRS Memo Indicates Civil Unions Are Marriages for Federal Tax Purposes, 2011 TAX Notes TODAY 216-5 (Nov. 8, 2011) (LEXIS, FEDTAX lib., TNT file, elec. cit. 2011 TNT 216-5).

${ }^{36}$ Rev. Rul. 2013-17, 2013-38 I.R.B. 201.

${ }^{37}$ See Carlton Smith \& Edward Stein, Dealing with DOMA: Federal Non-Recognition Complicates State Income Taxation of Same-Sex Relationships, 24 COLUM. J. GENDER \& L. 29 (2012) (although the relevant portion of the federal Defense of Marriage of Act has since been declared unconstitutional, United States v. Windsor, 570 U.S. 133 S. Ct. 2675 (2013), the discussion of this issue in the article remains relevant to those in domestic partnerships, civil unions, and similar legal relationships because the Service denies them legal recognition for federal tax purposes).
} 
Third, even for those couples who voluntarily chose a civil union, domestic partnership, or other legal relationship in anticipation of avoiding the marriage penalty, the Service's position in the Proposed Regulations is inconsistent with its past treatment of such tax avoidance behavior. In the past, the Service has itself relied upon the principle of substance over form to argue that labels should not control questions of marital status but that the substance of the transaction should control. In particular, the Service has invoked the principle of substance over form to prevent taxpayers from manipulating their marital status by divorcing and remarrying each year for the sole purpose of achieving tax savings by not being "married" at the end of the taxable year. ${ }^{38}$ As mentioned above, only a small group of states have created marriage alternatives for their residents. The Proposed Regulations would favor the residents of those states over all others, because they would be given the option of securing all of the state-level rights and obligations of marriage that residents in other states could but without incurring the marriage penalty that similarly situated couples in other states would and without being subject to the many antiabuse rules in the Code that those couples must contend with (e.g., sections 108(e)(4), 267(a)(1), 302(c), 453(e), and 1031(f)). Put differently, the Proposed Regulations would permit couples to avoid the federal marriage penalty and the antiabuse rules that apply to married couples if they live in California or Nevada or Illinois, but not if they live in Georgia or Texas or Michigan. Compounding this differential treatment of similarly situated couples, in some states this option to avoid adverse tax consequences would be open only to same-sex couples or only to same-sex couples and a select group of different-sex couples. ${ }^{39}$ In contrast, recognizing civil unions, domestic partnerships, and similar relationships would correct this problem by ensuring that similarly situated couples are treated similarly throughout the nationin keeping with basic notions of horizontal equity.

Finally, it is inappropriate for the Service to determine tax policy based on taxpayer expectations of reaping nontax benefits because of a position taken by the Service. Here, the preamble to the Proposed Regulations specifically mentions taxpayer expectations regarding the treatment of their relationships for purposes of determining their Social Security benefits. The Social Security Administration - and not the Service - is charged with administering Social Security benefits. In the past, when the Federal Home Loan Bank Board (FHLBB) similarly took action for the sole purpose of facilitating taxpayers' achieving tax benefits, the Service resisted that position and litigated the issue all the way to the U.S. Supreme Court. ${ }^{40}$ Indeed, in the Supreme Court, Justices Blackmun and White chastised the FHLBB for its actions, expressing surprise "that an agency not responsible for tax matters would presume to dictate what is or is not a deductible loss for federal income tax purposes. ${ }^{\circ 1}$ Out of respect for the jurisdiction of a coordinate executive agency, the Service should not allow taxpayers' desired treatment of their relationship for Social Security purposes to dictate their treatment for federal tax purposes.

\footnotetext{
${ }^{38}$ Boyter v. Commissioner, 668 F.2d 1382 (4 ${ }^{\text {th }}$ Cir. 1981); Rev. Rul. 76-255, 1976-2 C.B. 40.

${ }^{39}$ See CAL. FAM. CODE $§ 297$ (b)(4) (2015) (restricting domestic partnerships to same-sex couples and different-sex couples in which at least one person is over 62 years old); N.J. STAT. ANN. § 37:1-30 (2015) (limiting civil unions to same-sex couples).

${ }^{40}$ Cottage Sav. Ass'n v. Commissioner, 499 U.S. 554 (1991).

${ }^{41} I d$. at 569 (Blackmun, J., dissenting).
} 


\section{Lack of Specific Statutory Provisions}

The preamble to the Proposed Regulations further justifies denying legal recognition to domestic partnerships, civil unions, and similar legal relationships because Congress has not enacted a specific statutory provision requiring these relationships to be treated as marriages for federal tax purposes. Yet, until the Windsor decision, Congress refused to treat even married same-sex couples as spouses for federal tax purposes. ${ }^{42}$ It is implausible to expect that Congress would have enacted a provision indicating that if the federal Defense of Marriage Act were ever struck down, only married spouses and not registered domestic partners or parties to a civil union could be treated as married. Moreover, the lack of a specific provision in the Code addressing the exact situation faced by a taxpayer has never been a barrier to the application of the principle of substance over form; indeed, the inability of Congress to timely address every situation faced by taxpayers is the raison d'être of that principle.

\section{Inconsistent Positions}

The Proposed Regulations purport to categorically deny recognition to domestic partnerships, civil unions, and similar legal relationships. At the same time, however, the Proposed Regulations treat taxpayers as married so long as any state, possession, or territory would recognize their marriage. These rules are inconsistent with each other in the case of the laws of the States for which they are principally relevant.

When Connecticut extended the right to marry to same-sex couples and phased out its civil union regime, it enacted a provision that recognizes all relationships that are substantially equivalent to marriage as a "marriage" in Connecticut:

A marriage, or a relationship that provides substantially the same rights, benefits and responsibilities as a marriage, between two persons entered into in another state or jurisdiction and recognized as valid by such other state or jurisdiction shall be recognized as a valid marriage in this state, provided such marriage or relationship is not expressly prohibited by statute in this state. ${ }^{43}$

This state statute recognizes alternative legal relationships as "a valid marriage" in Connecticut - and not only if these relationships are legally equivalent to a marriage, but also if they have "substantially" the same rights and obligations as a marriage. Thus, notwithstanding what seems to be a categorical denial of legal recognition to marriage alternatives, most (if not all) of the extant marriage alternatives should actually be treated as marriages for federal tax purposes under the Proposed Regulations because Connecticut (as well as New Hampshire and Massachusetts $)^{44}$ would recognize them as a "marriage."

\footnotetext{
42 1 U.S.C. $\S 7$, overruled by United States v. Windsor, 570 U.S. __, 133 S. Ct. 2675 (2013).

${ }^{43}$ CONN. GEN. STAT. § 46b-28a (2014).

${ }^{44}$ N.H. REV. STAT. ANN. § 457:45 ("A civil union legally contracted outside of New Hampshire, or any legal union other than a marriage that provides substantially the same rights, benefits and responsibilities as a marriage that is legally contracted outside of New Hampshire, shall be recognized as a marriage in this state ... ."); see Hunter v. Rose, 975 N.E.2d 857, 861-62 (Mass. 2012) (recognizing a California registered domestic partnership as a marriage for purposes of Massachusetts law); Elia-Warnken v. Elia, 972 N.E.2d 17, 19-21 (Mass. 2012) (recognizing a Vermont civil union as a marriage for purposes of Massachusetts law).
} 
For all of these reasons, we recommend that the Proposed Regulations, when finalized, reverse the Service's current position and instead afford legal recognition to domestic partnerships, civil unions, and similar legal relationships. Indeed, we recommend that the Service adopt the approach used by the States of Connecticut and New Hampshire and recognize not only relationships that are denominated "marriages" by a state, possession, territory, or foreign country but also recognize relationships that provide substantially the same rights, benefits, and responsibilities as a marriage in the respective jurisdiction.

\section{Conclusion}

We commend the Service for attempting to provide guidance that clarifies the tax treatment of same-sex and different-sex couples in the wake of the Obergefell and Windsor decisions. The Service's proposal to read the gendered terms relating to marital status in the Code in a gender-neutral fashion is laudable.

In contrast, the Service's proposed rule for determining taxpayers' marital status raises a number of problems and issues that seem to have escaped the notice of the drafters of the Proposed Regulations, and we recommend that the final Regulations should avoid these thorny issues and simply codify the existing deference to relevant local law when determining marital status for federal tax purposes.

Likewise, we recommend that the Service reverse its position in the Proposed Regulations regarding the treatment of domestic partnerships, civil unions, and similar legal relationships. We assert that legally recognizing these alternative relationship statuses for federal tax purposes would better fulfill the Service's professed purposes in issuing the Proposed Regulations, would result in fairer treatment of similarly situated taxpayers, would render tax considerations neutral in choosing between the different relationship statuses, and would better accord with the reality that several states already treat these relationships as marriages for purposes of their laws. 